\title{
Drying Behavior and Mathematical Modelling of Bottle Gourd
}

\author{
Kukadiya Vishal*, D. and Akbari Sanjay, H.
}

Department of Food Plant Operations, College of Food Processing Technology and Bioenergy, Anand, Gujarat, India

*Corresponding author: vishal2041990@gmail.com (ORCID ID: 0000-0002-5287-6915)

Paper No. 796

Received: 03-07-2019

Revised: 05-10-2019

Accepted: 24-11-2019

\begin{abstract}
Bottle Gourd slabs of $10 \times 10 \times 3 \mathrm{~mm}, 10 \times 10 \times 5 \mathrm{~mm}$ and $10 \times 10 \times 7 \mathrm{~mm}$ were dehydrated by fluidized bed drying technique with a sample size of $100 \mathrm{~g}$ at air temperature of 50,60 and $70^{\circ} \mathrm{C}$ at air velocity of $10 \mathrm{~m} / \mathrm{s}$. The drying rate is high for the slabs of $10 \times 10 \times 3 \mathrm{~mm}$ at $70^{\circ} \mathrm{C}$. Moisture diffusivity of bottle gourd slabs dried under fluidized bed drying conditions was found in the range of $1.03 \times 10^{-09}$ to $6.18 \times 10^{-09} \mathrm{~m}^{2} / \mathrm{s}$ water activity varied from 0.318 to 0.393 for fluidized bed dryer. The product of fluidized bed dryer at $70^{\circ} \mathrm{C}(10 \times 10 \times 3 \mathrm{~mm})$ has best quality in terms of water activity. The experimental data was fitted to page model other than the mathematical models available in the literature. The fluidized bed dried product for $10 \times 10 \times 5 \mathrm{~mm}$ slab at $60^{\circ} \mathrm{C}$ was of best quality in terms of color.

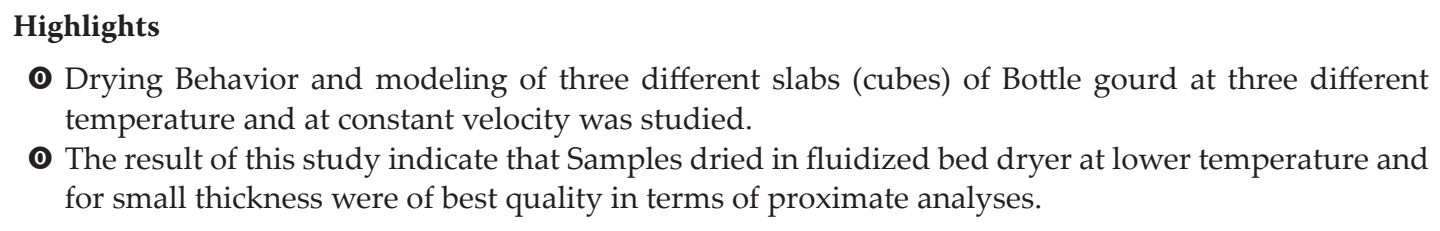

Keywords: Fluidized bed drying, moisture diffusivity, proximate analysis, mathematical modelling, water activity

Bottle gourd is a wonder vegetable. It is used all over the world as a vegetable in food preparation because of its unique flavor. Growth in popularity of convenient foods in many countries has stimulated increasing demand for high quality dehydrated bottle gourd products like bottle gourd flakes, bottle gourd seed oil and bottle gourd powder. Fluidized bed drying technique is a very convenient method of drying for heat sensitive food materials as it prevents them from overheating (Giner and Cavelo 1987). Results have shown that drying of vegetables in a fluidized bed dryer produces dry vegetable pieces of excellent quality in a much shorter time than in continuous belt dryers which are generally used (Bobic 2002). The study of drying kinetics helps in the design, simulation and optimization of drying processes.

\section{MATERIALS AND METHODS}

Locally available bottle gourd was used in the investigation. Bottle gourd had initial moisture content of $16.48 \mathrm{~g}$ of water/ g of dry matter. The initial moisture content of bottle gourd slices was determined by oven drying method (Ranganna 2000).

\section{Drying}

Tray dryer and fluidized bed dryer was used for this investigation. peeled bottle gourds were cut into different dimensions i.e. cuboidal, as per the requirement of the investigation. The cuboidal shaped bottle gourds slices were cut into dimensions of $10 \times 10 \times 3 \mathrm{~mm}, 10 \times 10 \times 5 \mathrm{~mm}$ and $10 \times 10 \times 7 \mathrm{~mm}$ i.e. the dimensions of the cut pieces of bottle gourd slices were measured, with the help of a micrometer having least count of $0.001 \mathrm{~mm}$. Drying of bottle gourd slabs were carried out for fluidized bed dryer at 50,60 and $70^{\circ} \mathrm{C}$ at air velocity of $10 \mathrm{~m} / \mathrm{s}$ respectively. The drying was terminated at moisture 
content of about 6 per cent wet basis which was found safe for storage.

\section{Moisture content of bottle gourd samples during drying}

Moisture content of bottle gourd slabs during drying experiments at various time intervals was determined by calculating mass of dry matter of the sample. Moisture contents at various times were calculated by the formula:

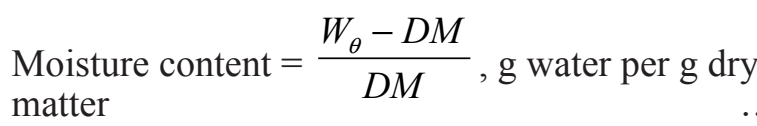

\section{Dry matters}

The dry matter percentage and weight of dry matter in sample were calculated as,

$$
\mathrm{DM}(\%)=100.0-\mathrm{IMC}(\% \mathrm{wb})
$$

Weight of DM $=$ Initial mass of sample $\times \frac{D M(\%)}{100}$

\section{Moisture Ratio}

The moisture ratio (MR) at each moisture content level was determined by the following equation:

$$
M R=\frac{M-M_{e}}{M_{o}-M_{e}}
$$

\section{Drying rate}

The drying rate of sample was calculated by following mass balance equation,

$$
R=\frac{W M L(k g)}{\text { Time interval }(\min ) \times(k g)}
$$

Where, $W \theta=$ weight of the sample at time $\theta, g$, DM $=$ dry matter of the sample, $g$, IMC = Initial moisture content, $\mathrm{MR}=$ Moisture ratio, $\mathrm{M}=$ Moisture content at any time (d.b.), $M_{o}=$ Initial moisture content (d.b.), $M_{e}=$ Equilibrium moisture content; EMC (d.b.), R $=$ Drying rate at time $\theta, \mathrm{kg}$ water $/ \mathrm{kg}, \mathrm{min}, \mathrm{WML}=$ Initial weight of sample - Weight.

\section{Moisture diffusivity during drying}

In drying, diffusivity is used to indicate the flow of moisture out of material. In falling rate period of drying, moisture transfer within the food is mainly by molecular diffusion. The falling rate period of biological materials is best described by Fick's second law of diffusion (Crank 1958).

\section{Mathematical Models under Study}

The experimental data were fitted to following mostly used drying models and the best was chosen for predicting drying behavior of dried bottle gourd slabs samples.To determine the most suitable drying equation, the experimental drying data were fitted in the various drying models (Table 1).

Table 1: Mathematical models used under drying study

\begin{tabular}{lll}
\hline Model equation & Name & Reference \\
\hline$M R=\exp \left(-k t^{n}\right)$ & Page & Zhang and Litchfield (1991) \\
$M R=a \exp (-k t)$ & $\begin{array}{l}\text { Henderson } \\
\text { and Pabis }\end{array}$ & $\begin{array}{l}\text { Henderson and Pabis } \\
(1961)\end{array}$ \\
$M R=A T^{B}$ & Power law & Chandra and Sing (1995) \\
\hline
\end{tabular}

\section{RESULTS AND DISCUSSION}

\section{Effect of process variables on drying time for bottle gourd slices}

The change in moisture content of bottle gourd slabs with elapsed drying time, at three drying temperature levels of 40,50 and $60{ }^{\circ} \mathrm{C}$ and three thickness levels, $10 \times 10 \times 3 \mathrm{~mm}, 10 \times 10 \times 5 \mathrm{~mm}$ and $10 \times 10 \times 7 \mathrm{~mm}$ at air velocity level of $10 \mathrm{~m} / \mathrm{s}$ for fluidized bed dryer. The drying time for fluidized bed drying condition for bottle gourd slabs of $10 \times 10 \times 3 \mathrm{~mm}$ at 50,60 and $70{ }^{\circ} \mathrm{C}$ was $2.16,1.66$ and $1.33 \mathrm{~h}$, respectively. Similarly, the drying time for bottle gourd slabs of $10 \times 10 \times 5 \mathrm{~mm}$ dried at 50,60 and $70{ }^{\circ} \mathrm{C}$ was found to be $2.33,1.83$ and $1.50 \mathrm{~h}$, and the drying time for bottle gourd slabs of $10 \times 10 \times 7$ $\mathrm{mm}$ dried at 50,60 and $70{ }^{\circ} \mathrm{C}$ was found to be 2.50, 2.00 and $1.66 \mathrm{~h}$. As the drying air temperature was increased from 50 to $70{ }^{\circ} \mathrm{C}$, the drying time reduced. The drying curves of bottle gourd slices under all conditions indicated that the drying process is unaffected by air velocity, but temperatures play a major role in drying. 


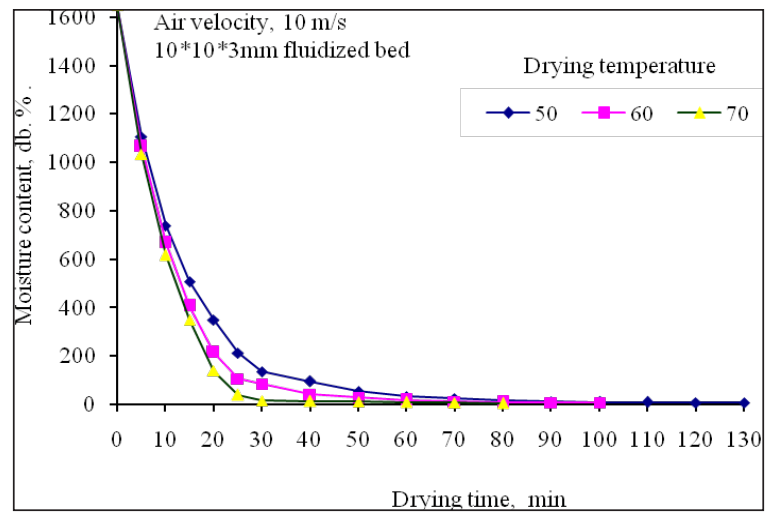

Fig. 1: Variation in moisture content with drying time at different temperature

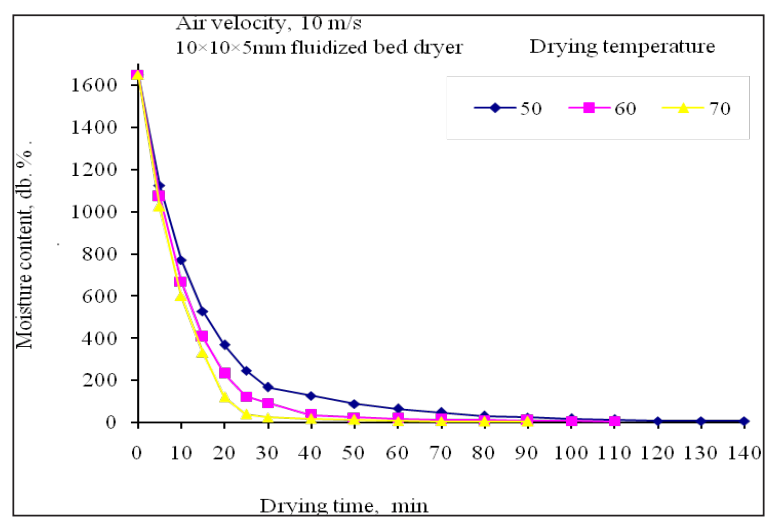

Fig. 2: Variation in moisture content with drying time at different temperature

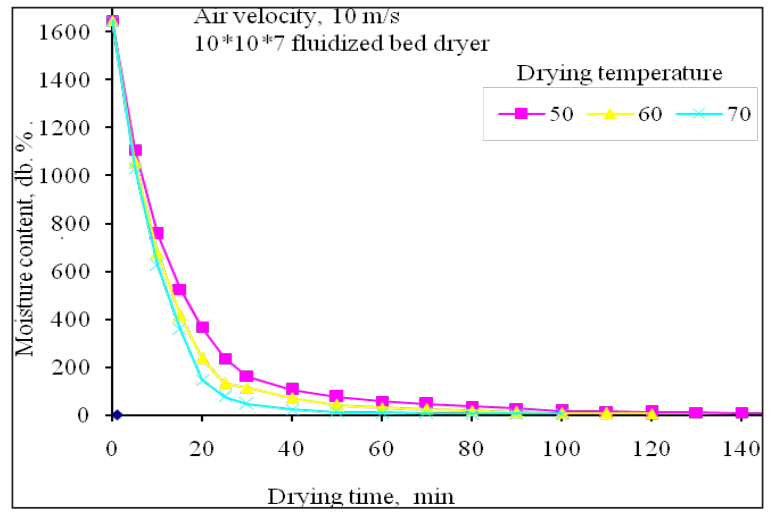

Fig. 3: Variation in moisture content with drying time at different temperature

\section{Drying rate}

The drying rates decreased for bottle gourd slabs of $10 \times 10 \times 3 \mathrm{~mm}$ as compared to slabs of $10 \times 10 \times 7 \mathrm{~mm}$ at different drying air temperature (50, 60 and 70 ${ }^{\circ} \mathrm{C}$ ) for drying rate for slab of $10 \times 10 \times 7 \mathrm{~mm}$ is lower compared with that of slabs of $10 \times 10 \times 3 \mathrm{~mm}$ in all the three temperature levels $\left(50,60\right.$ and $70^{\circ} \mathrm{C}$ ) for fluidized bed drying experiments. The drying rate is high for the slabs of $10 \times 10 \times 3 \mathrm{~mm}$ at $70{ }^{\circ} \mathrm{C}$ for fluidized bed drying. A second order polynomial relationship was found to have fitted adequately to desirable variations in the drying rates with moisture content at all three experimental temperatures and thickness is represented by equation 6 with their coefficient of correlation values presented in Table 2 .

$$
R=A x^{2}+B x+C
$$

Where, $R$ is the rate of drying in $g$ water evaporated per $g$ dry matter-min. $A, B$ and $C$ are constants and $x$ is the moisture content in $g$ water per $g$ of dry matter. It is also seen that the values of coefficient of correlation are more than 0.97 for fluidized bed dryer, at all the process temperatures which shows the good correlation among the predicted and observed values.

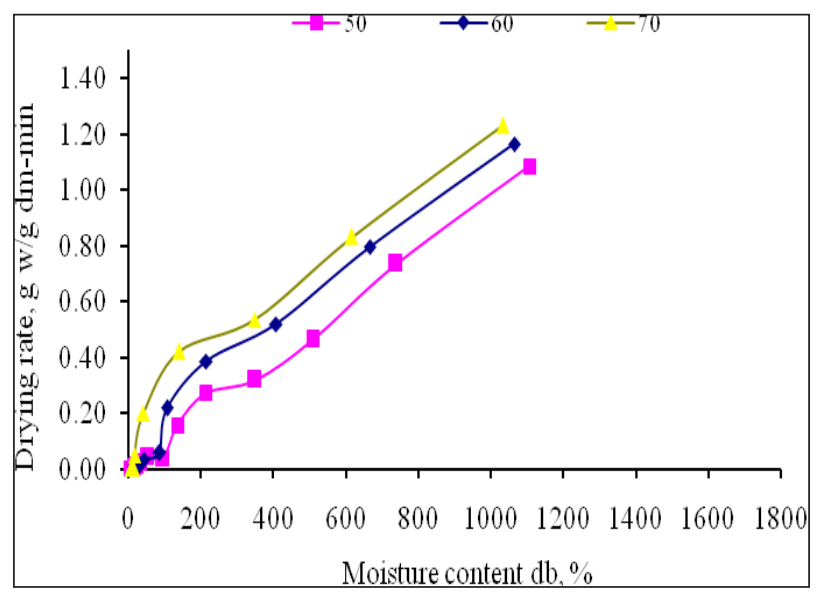

Fig. 4: Drying Rate Curves with Moisture Content at different Temperature $(10 \times 10 \times 3 \mathrm{~mm})$

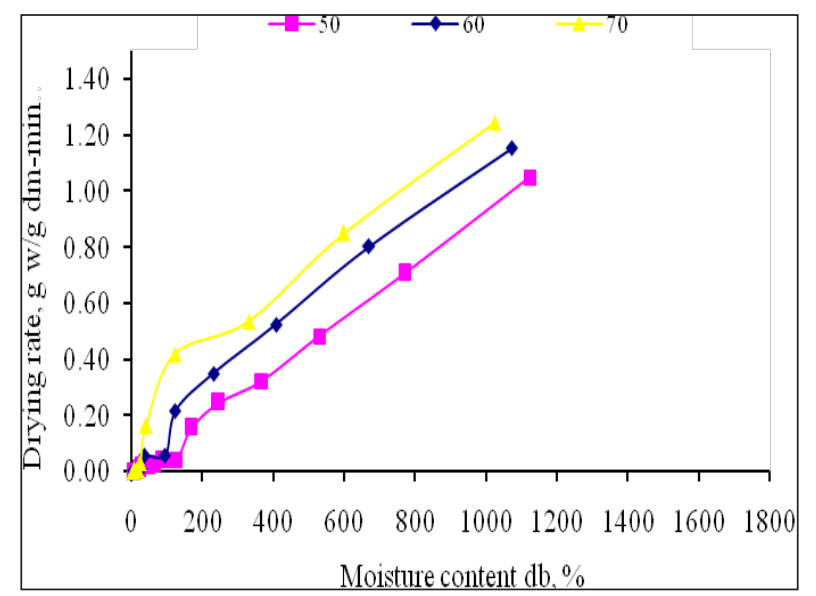

Fig. 5: Drying Rate Curves With Moisture Content At different Temperature $(10 \times 10 \times 5 \mathrm{~mm})$ 


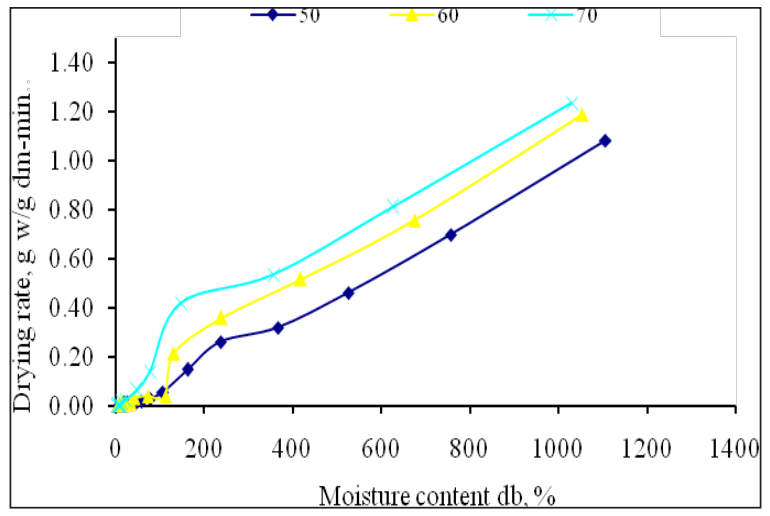

Fig. 6: Drying rate curves with moisture content at different temperature $(10 \times 10 \times 7 \mathrm{~mm})$

\section{Moisture diffusivity of bottle gourd slabs}

The variation in $\ln (\mathrm{MR})$ with drying time under various process conditions is presented in Fig.. The variation was found to be linear with inverse slope. The slope became steeper with increase in drying air temperature. Moisture diffusivity of bottle gourd slabs dried under fluidized bed drying conditions was found in the range of $1.03 \times 10-09$ to $6.18 \times$ $10-09 \mathrm{~m}^{2} / \mathrm{s}$.

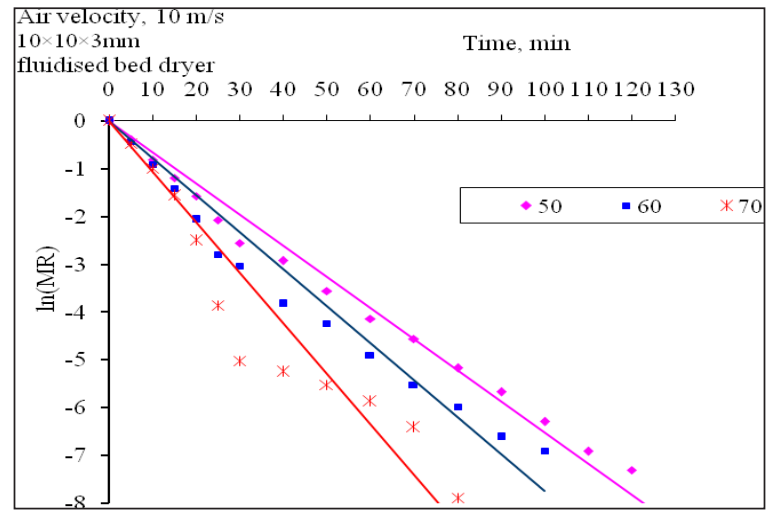

Fig. 7: Variation in $\ln (\mathrm{MR})$ versus time for fluidized bed dryer at different temperature $(10 \times 10 \times 3 \mathrm{~mm})$

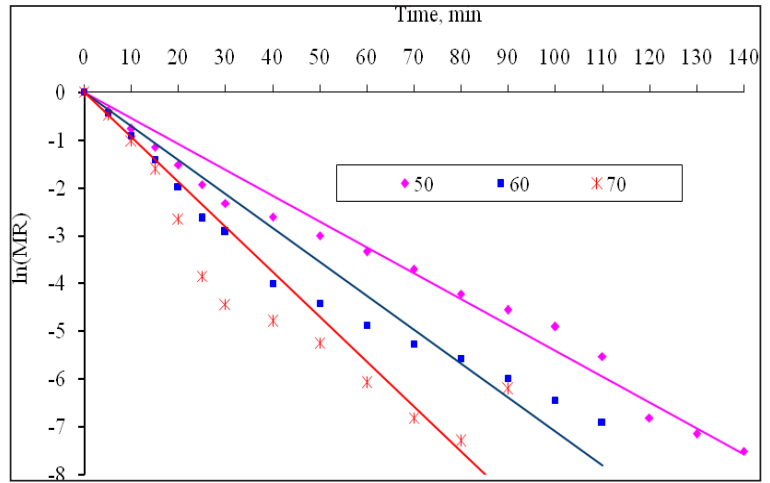

Fig. 8: Variation in $\ln (\mathrm{MR})$ versus time for fluidized bed dryer at different temperature $(10 \times 10 \times 5 \mathrm{~mm})$

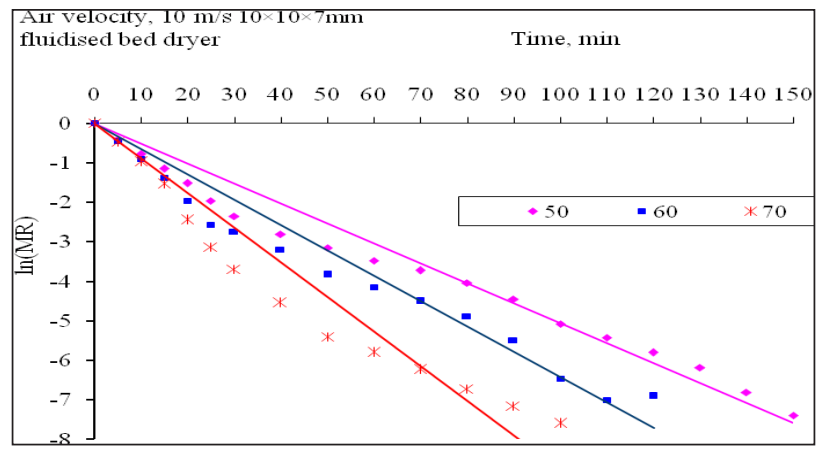

Fig. 9: Variation in $\ln (\mathrm{MR})$ versus time for fluidized bed dryer at different temperature $(10 \times 10 \times 7 \mathrm{~mm})$

Table 2: Moisture diffusivity values for fluidized bed dried bottle gourd slabs

\begin{tabular}{lllll}
\hline Shape & $\begin{array}{l}\text { Drying } \\
\text { tem. }\left({ }^{\circ} \mathbf{C}\right)\end{array}$ & $\begin{array}{l}\text { Regression } \\
\text { equation }\end{array}$ & $\begin{array}{l}\text { Moisture } \\
\text { diffusivity } \\
\left(\mathbf{m}^{2} / \mathbf{s}\right)\end{array}$ & $\mathbf{R}^{2}$ \\
\hline $10 \times 10 \times 3$ & 50 & $\mathrm{y}=-0.0009 \mathrm{x}-0.460$ & $3.97 \times 10^{-09}$ & 0.981 \\
$\mathrm{~mm}$ & 60 & $\mathrm{y}=-0.0012 \mathrm{x}-0.526$ & $5.30 \times 10^{-09}$ & 0.973 \\
& 70 & $\mathrm{y}=-0.0014 \mathrm{x}-0.784$ & $6.18 \times 10^{-09}$ & 0.959 \\
& 50 & $\mathrm{y}=-0.0014 \mathrm{x}-0.351$ & $2.29 \times 10^{-09}$ & 0.985 \\
$10 \times 10 \times 5$ & 60 & $\mathrm{y}=0.0022 \mathrm{x}-0.691$ & $3.62 \times 10^{-09}$ & 0.954 \\
$\mathrm{~mm}$ & 70 & $\mathrm{y}=-0.0261 \mathrm{x}-0.863$ & $4.10 \times 10^{-09}$ & 0.983 \\
& 50 & $\mathrm{y}=-0.0007 \mathrm{x}-0.578$ & $5.56 \times 10^{-10}$ & 0.986 \\
$10 \times 10 \times 7$ & 60 & $\mathrm{y}=-0.0009 \mathrm{x}-0.607$ & $7.15 \times 10^{-10}$ & 0.975 \\
$\mathrm{~mm}$ & 70 & $\mathrm{y}=-0.0013 \mathrm{x}-0.713$ & $1.03 \times 10^{-09}$ & 0.949 \\
\hline
\end{tabular}

ANOVA, carried out to study the effect of process variables on moisture diffusivity revealed that size had significant effect on moisture diffusivity.The value lie in the range of $10-10$ to $10-11 \mathrm{~m}^{2} / \mathrm{s}$ for food materials.

Table 3: ANOVA showing the effect of process variables on moisture diffusivity of bottle gourd slabs dried in a fluidized bed dryer

\begin{tabular}{|c|c|c|c|c|c|c|c|}
\hline $\begin{array}{l}\text { Sl. } \\
\text { No. }\end{array}$ & Source & DF & SS & MS & F & $\mathrm{SE}(\mathrm{m})$ & $\mathrm{CD}(1)$ \\
\hline 1 & Temp. & 2 & 87.3766 & 43.6883 & $4176.996^{* *}$ & 0.0341 & 0.1389 \\
\hline 2 & Size & 2 & 10.2991 & 5.14957 & $492.346^{* *}$ & 0.03409 & 0.1389 \\
\hline 3 & Total & 4 & 2.72981 & 0.682454 & $65.249^{* *}$ & 0.05905 & 0.2405 \\
\hline 4 & Error & 18 & 0.188267 & 0.0104593 & & & \\
\hline
\end{tabular}

\section{Modeling of drying behavior of bottle gourd slabs}

Experimental data on drying of bottle gourd slabs were fitted into three models as presented in Table 
Table 4: Values for model constants and statistical parameters used in fluidized bed drying of bottle gourd slabs

\begin{tabular}{|c|c|c|c|c|c|c|c|c|c|}
\hline \multirow{2}{*}{$\begin{array}{l}\text { Name of } \\
\text { Model }\end{array}$} & \multirow{2}{*}{ Slabs thickness } & \multirow{2}{*}{$\begin{array}{l}\text { Air } \\
\text { temp. }\end{array}$} & \multicolumn{4}{|c|}{ Drying constant } & \multicolumn{3}{|c|}{ Statistical parameters } \\
\hline & & & $\mathbf{K}$ & $\mathbf{N}$ & $\mathbf{A}$ & B & $\mathbf{R}^{2}$ & $x^{2}$ & $\mathrm{E}_{\mathrm{RMS}}$ \\
\hline \multirow{12}{*}{ 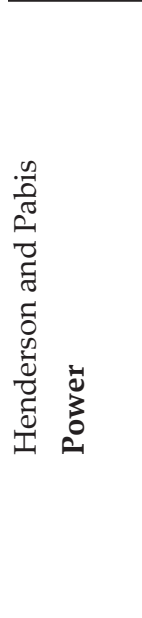 } & \multirow[t]{3}{*}{$10 \times 10 \times 3 \mathrm{~mm}$} & 50 & 0.08 & - & 0.928 & - & 0.9960 & 0.0006 & 0.0240 \\
\hline & & 60 & 0.096 & - & 0.945 & - & 0.9970 & 0.0006 & 0.0236 \\
\hline & & 70 & 0.108 & - & 0.960 & - & 0.9980 & 0.0030 & 0.0159 \\
\hline & \multirow[t]{4}{*}{$10 \times 10 \times 5 \mathrm{~mm}$} & 50 & 0.075 & - & 0.933 & - & 0.9960 & 0.0005 & 0.0225 \\
\hline & & 60 & 0.095 & - & 0.954 & - & 0.9980 & 0.0002 & 0.0147 \\
\hline & & 70 & 0.110 & - & 0.967 & - & 0.9990 & 0.0002 & 0.0125 \\
\hline & & 50 & 0.076 & - & 0.947 & - & 0.9970 & 0.0006 & 0.0239 \\
\hline & \multirow[t]{3}{*}{$10 \times 10 \times 7 \mathrm{~mm}$} & 60 & 0.093 & - & 0.973 & - & 0.9990 & 0.0001 & 0.0105 \\
\hline & & 70 & 0.016 & - & 0.982 & - & 0.9990 & 0.0001 & 0.0102 \\
\hline & & 50 & 0.081 & 0.834 & - & - & 0.9980 & 0.0003 & 0.0208 \\
\hline & \multirow[t]{3}{*}{$10 \times 10 \times 3 \mathrm{~mm}$} & 60 & 0.072 & 0.877 & - & - & 0.9980 & 0.0003 & 0.0233 \\
\hline & & 70 & 0.063 & 0.916 & - & - & 0.9980 & 0.0003 & 0.0171 \\
\hline \multirow{10}{*}{ 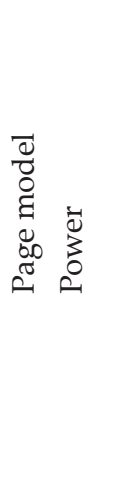 } & & 50 & 0.087 & 0.838 & - & - & 0.9980 & 0.0003 & 0.0155 \\
\hline & \multirow[t]{3}{*}{$10 \times 10 \times 5 \mathrm{~mm}$} & 60 & 0.073 & 0.888 & - & - & 0.9990 & 0.0002 & 0.0119 \\
\hline & & 70 & 0.065 & 0.925 & - & - & 0.9990 & 0.0002 & 0.0135 \\
\hline & & 50 & 0.089 & 0.862 & - & - & 0.9990 & 0.0001 & 0.0105 \\
\hline & \multirow[t]{3}{*}{$10 \times 10 \times 7 \mathrm{~mm}$} & 60 & 0.084 & 0.933 & - & - & 1.0000 & 0.0001 & 0.0080 \\
\hline & & 70 & 1.16 & 0.96 & - & - & 0.9990 & 0.0002 & 0.0121 \\
\hline & & 50 & - & - & 3.754 & 01.027 & 0.947 & 0.069 & 0.2462 \\
\hline & \multirow[t]{3}{*}{$10 \times 10 \times 3 \mathrm{~mm}$} & 60 & - & - & 4.442 & -1.165 & 0.951 & 0.085 & 0.2703 \\
\hline & & 70 & - & - & 5.265 & -1.294 & 0.938 & 0.103 & 0.2924 \\
\hline & & 50 & - & - & 3.527 & -0.978 & 0.953 & 0.064 & 0.2389 \\
\hline \multirow{5}{*}{ 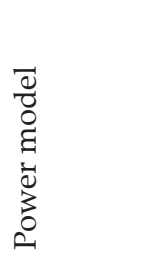 } & \multirow{3}{*}{$10 \times 10 \times 5 \mathrm{~mm}$} & 60 & - & - & 4.414 & -1.157 & 0.954 & 0.0786 & 0.2610 \\
\hline & & 70 & - & - & 5.411 & -1.317 & 0.945 & 0.0930 & 0.2810 \\
\hline & & 50 & - & - & 3.539 & -0.988 & 0.952 & 0.0605 & 0.2327 \\
\hline & \multirow{2}{*}{$10 \times 10 \times 7 \mathrm{~mm}$} & 60 & - & - & 4.054 & -1.114 & 0.958 & 0.0729 & 0.2525 \\
\hline & & 70 & & & 4.944 & -1.255 & 0.948 & 0.0853 & \\
\hline
\end{tabular}

1. The goodness of fit of each model was determined by estimating the coefficient of determination, The statistical parameters for different models used for fluidized bed dried bottle gourd slabs have been presented in Table 5. It was observed that in all models the values of $\mathrm{R}^{2}$ were greater than 0.90 indicating a good fit except for power law model. The values of Coefficient of determination $\left(R^{2}\right)$ for Page model at all levels of temperatures were greater than 0.997 and the values of root mean square error $\left(E_{R M S}\right)$, reduced mean square of the deviation $\left(\chi^{2}\right)$ were in range 0.0177 to $0.0190,0.0003$ to 0.0004 respectively which were lower than the rest of other two models (Henderson \& Pabis and Power law). Hence, Page model was found to be the most satisfactory than the other models to represent the thin-layer drying of bottle gourd slab.

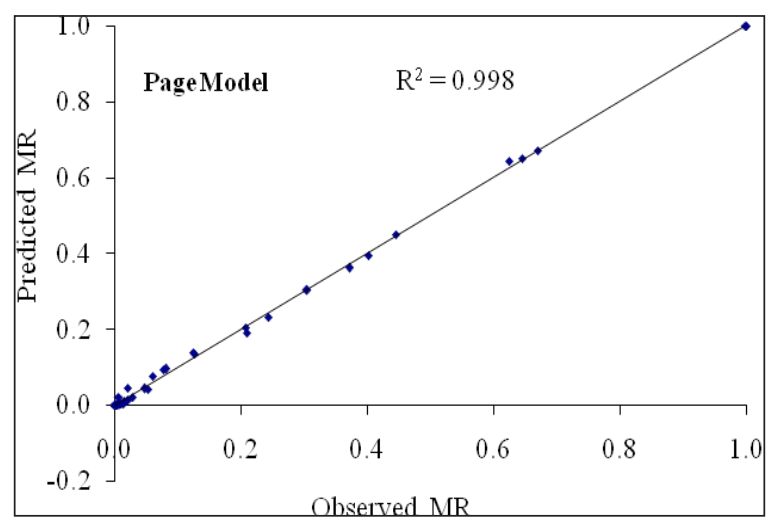

Fig. 10: Experimental and predicted values of moisture ratio by Page model $(10 \times 10 \times 3 \mathrm{~mm})$. 


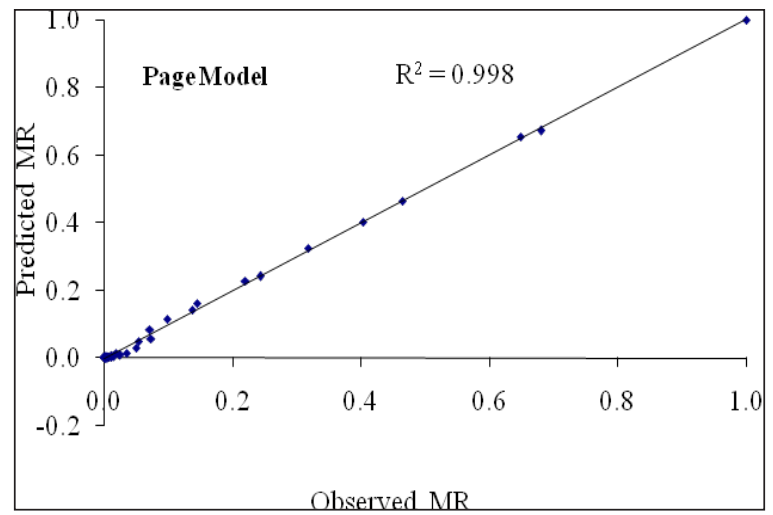

Fig. 11: Experimental and predicted values of moisture ratio by Page model $(10 \times 10 \times 5 \mathrm{~mm})$

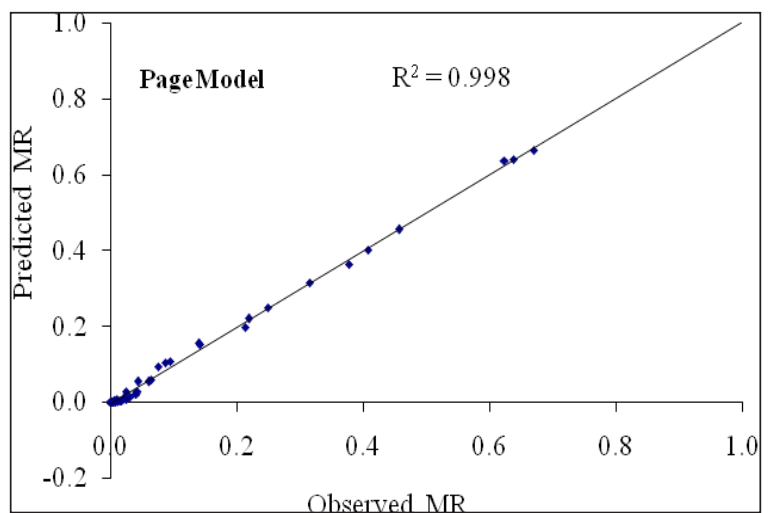

Fig. 12: Experimental and predicted values of moisture ratio by Page model $(10 \times 10 \times 7 \mathrm{~mm})$

\section{Water activity of dehydrated bottle gourd samples}

The water activity scale extends from 0 (bone dry) to 1 (pure water) but most foods have a water activity level in the range of 0.2 (very dry foods) to 0.99 (moist fresh foods). It revealed that as the temperature increased and thickness water activity decreased significantly.

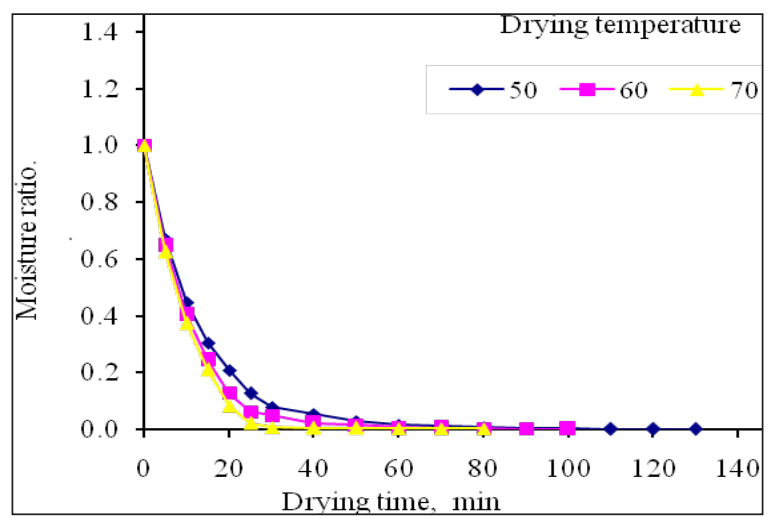

Fig. 13: Effect of temperature on moisture ratio of dried bottle gourd slabs $(10 \times 10 \times 3 \mathrm{~mm})$ at $10 \mathrm{~m} / \mathrm{s}$
The minimum water activity reported for the sample of $10 \times 10 \times 3 \mathrm{~mm}$ at $70^{\circ} \mathrm{C}$ is 0.318 fluidized bed dryer, which is in within safe limit. The ANOVA for water activity is presented in Table 6. From this table, it can be seen that effect of temperature was significant on water activity at 1 per cent level of significance.

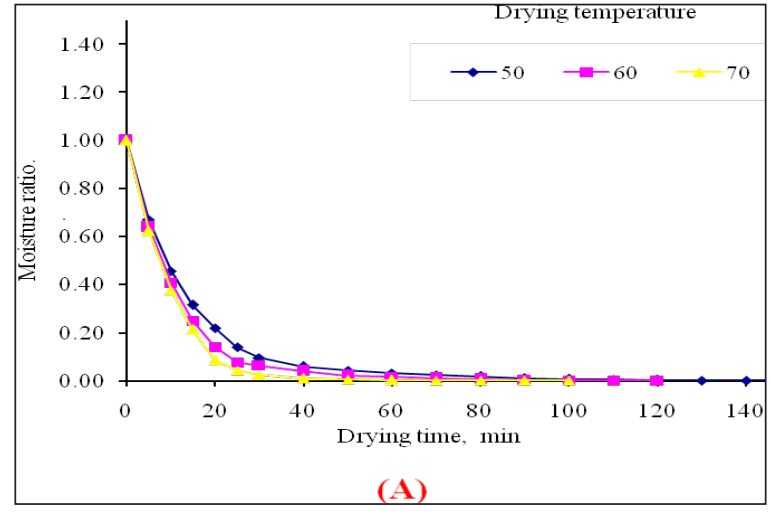

Fig. 14: Effect of temperature on moisture ratio of dried bottle gourd slabs $(10 \times 10 \times 5 \mathrm{~mm})$ at $10 \mathrm{~m} / \mathrm{s}$

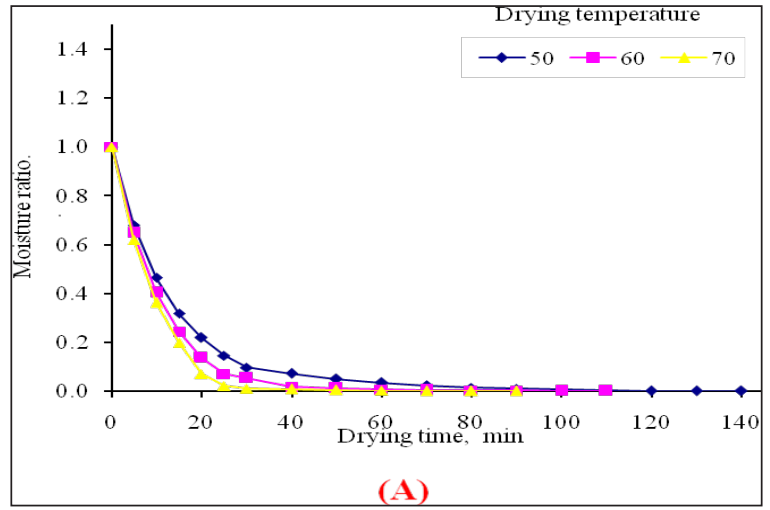

Fig. 15: Effect of temperature on moisture ratio of dried bottle gourd slabs $(10 \times 10 \times 7 \mathrm{~mm})$ at $10 \mathrm{~m} / \mathrm{s}$

Table 5: Water activity $\left(\mathrm{a}_{\mathrm{w}}\right)$ of fluidized bed dried bottlegourd powder

\begin{tabular}{llllllll}
\hline Source & DF & SS & MS & F & SE(m) & CD(5) & CD(1) \\
\hline Temp. & 2 & 0.0055 & 0.002787 & $38.180^{* *}$ & 0.00285 & 0.0084 & 0.0116 \\
Size & 2 & 0.0110 & 0.005534 & $75.821^{* *}$ & 0.002848 & 0.0084 & 0.0116 \\
Total & 4 & 0.0005 & 0.000136 & 1.864 & 0.004933 & 0.0146 & 0.0201 \\
Error & 18 & 0.0013 & $7.3 \mathrm{e}-005$ & & & & \\
\hline
\end{tabular}

$C V=2.3760,{ }^{* *}$ Significant at $1 \%$ level of significance

\section{CONCLUSION}

Drying of bottle gourd slabs occurred only in falling rate drying period. Constant rate drying period was absent throughout the drying process of bottle gourd slices dried under any air temperature. 
Moisture diffusivity of slab of $10 \times 10 \times 3 \mathrm{~mm}$ is higher compared to $10 \times 10 \times 5 \mathrm{~mm}$ and $10 \times 10 \times 5 \mathrm{~mm}$ is higher compared to $10 \times 10 \times 7 \mathrm{~mm}$ in fluidized bed drying conditions. Moisture diffusivity of bottle gourd slabs dried under fluidized bed drying conditions was found in the range of $1.03 \times 10^{-09}$ to $6.18 \times 10^{-}$ ${ }^{09} \mathrm{~m}^{2} / \mathrm{s}$. Page model gave better fit than the power model and Henderson \& Pabis model in fluidized bed dryer. The best quality of dehydrated bottle gourd slabs were obtained from samples dried at lower temperature in fluidized bed dryer. Samples dried in fluidized bed dryer at lower temperature were of best quality in terms of color,water activity and proximate analysis than tray dried product. The sensory evulation shows that the product of fluidized bed dryer of $10 \times 10 \times 3 \mathrm{~mm}$ at $70^{\circ} \mathrm{C}$ have good quality.

\section{REFERENCES}

Abe, T. and Afzal, T.M. 1997. Thin layer infrared radiation drying of rough rice. Journal of Agricultural Engineering Research, 67: 289-297.

Anonymous. 1987. Agricultural Situation in India, Government of India Publications, Krishi Bhawan, New Delhi XLII(7): 662.

Begum, S. and Brewer, M.S. 2001. Physical, chemical and sensory quality of microwave blanched snow peas. Journal of Food Quality, 24(6): 479-493.

Biennial Report, 2011 \& 2012. AICRP on Post Harvest Technology, CTAE, MPUAT Udaipur.

Bobic, Z., Baumani and Curic, D. 2002. Rehydration ratio of fluid bed dried vegetables. Sadhana, 27: 365 - 374.

Brooker, D.B., Bakker, F.W. and Hall, C.W. 1974. Drying and Storage of Grains and Oilseeds. The AVI Publishing Company, Inc. Westport, Connecticut, pp. 56-71.

Barton, G. 1975. The Mathematics of Diffusion $2^{\text {nd }}$ edn. Physics Bulletin, 26(11): 500-501.

Crank, J. 1958. The Mathematics of Diffusion. The Mathematical Gazette, 42(340): 165.

Chandra, P. K., Singh, R.P. 1995. Applied numerical methods for food and Agricultural engineers press, Boca Raton, FL. 163-167. CRC.

Denloye, O.O.A and Botterill, M.S.J. 1978. Bed to surface heat transfer in a fluidized bed of large particles. Powder Technology, 19: 197 - 203.

Fakuoka, M., Watanabe, H., Mihori, T. and Shimada, S. 1994. Moisture diffusivity in a dry soybean seed measured using pulsed-field-gradient NMR. Journal of Food Engineering, 23: 533-541.

Geldart, D. 1973. Types of gas fluidization. Powder Technology, 7(5): 285-292.

Giner, S.A. and Calvelo, A. 1987. Modelling of Wheat Drying in Fluidized Beds. Journal of Food Science, 52(5): 1358-1363.

Goyal, R.K.O.M. and Bhargava, V.K. 2008. Mathematical Modeling of Thin Layer Drying Kinetics of Apple in Tunnel Dryer. International Journal of Food Engineering, 4(8).

Hatamipour, M. and Mowla, D. 2002. Shrinkage of carrots during drying in an inert medium fluidized bed. Journal of Food Engineering, 55(3): 247-252.

Henderson, S.M. and Pabis, S. 1961. Grain drying theory I. Temperature effect on drying coefficient. Journal of Agricultural Engineering Research, 6(3): 169-174.

Jain, N.K., Sharma, K.C. and Feth, P. 2010. Studies on development of pilot plant for processing and value addition of bottle gourd for retention of bioactive components. Biennial Report, 2011 \& 2012. AICRP on Post Harvest Technology, CTAE, MPUAT Udaipur.

Srikiatden, J. and Roberts, J.S. 2006. Measuring moisture diffusivity of potato and carrot (core and cortex) during convective hot air and isothermal drying. Journal of Food Engineering, 74(1): 143-152.

Krokida, M.K., Karathanos, V.T., Maroulis, Z.B. and MarinosKouris, D. 2003. Drying kinetics of some vegetables. Journal of Food Engineering, 59(4): 391-403.

Lahsasni, S., Kouhila, M., Mahrouz, M., Mohamed, L.A., and Agorram, B. 2004. Characteristic Drying Curve and Mathematical Modeling of Thin-Layer Solar Drying of Prickly Pear Cladode (Opuntia ficus Indica). Journal of Food Process Engineering, 27(2): 103-117.

Magee, T.R.A. and Bransburg, T. 1995. Measurement of thermal diffusivity of potato, malt bread and wheat flour. Journal of Food Engineering, 25(2): 223-232.

Movagharnejad, K. and Nikzad, M. 2007. Modeling of tomato drying using artificial neural network. Computers and Electronics in Agriculture, 59(1-2): 78-85.

Navarri, P. and Andrieu, J. 1993. High-intensity infrared drying study. Chemical Engineering and Processing: Process Intensification, 32(5): 311-318.

Palipane, K.B. and Driscoll, R.H. 1994. The thin-layer drying characteristics of macadamia in-shell nuts and kernels. Journal of Food Engineering, 23(2): 129-144.

Pandevishakha, K. 1998. A study on dehydration and shelf- life characteristics of selected vegetables. Unpublished Master of Engineering, thesis, CTAE, MPUAT, Udaipur.

Pruthi, J.S. 1976. Spices and Condiments. National Book Trust, New Delhi, 269.

Ranganath, D.R. and Dubash, P.J. 1981. Loss of colour and vitamins on dehydration of vegetables. Indian Food Packer, 1: $4-10$.

Ranganna, S. 2000. Handbook of Analysis and quality control for fruits and vegetable products. Tata McGraw Hill Publishing Co. Ltd., New Delhi.

Rawle, K.P. 1999. Studies on drying characteristics and manorial value of water hyachinth, unpublished Master of Engineering thesis, CTAE, MPUAT, Udaipur.

Rodrigues, A.C.C., Cunha, R.L. and Hubinger, M.D. 2003. Rheological properties and colour evaluation of papaya 


\section{ardarasion}

during osmotic dehydration processing. Journal of Food Engineering, 59(2-3): 129-135.

Rossello, C., Canellas, J., Simal, S. and Berna, A. 1992. Simple mathematical model to predict the drying rates of potatoes. Journal of Agricultural and Food Chemistry, 40(12): 2374-2378.

Sharma, R. and Lal, D. 1999. Changes In Some Water Soluble Vitamins During Preparation and Storage of Khoa. J. Food Sci. Technol., 36(4): 349-351.

Scala, K. and Crapiste, G. 2008. Drying kinetics and quality changes during drying of red pepper. LWT - Food Science and Technology, 41(5): 789-795.

Senadeera, W., Bhandari, B.R., Young, G. and Wijesinghe, B. (2005). Modeling Dimensional Shrinkage of Shaped Foods in Fluidized Bed Drying. Journal of Food Processing and Preservation, 29(2): 109-119.

Senadeera, W., Bhandari, B.R., Young, G. and Wijesinghe, B. 2003. Influence of shapes of selected vegetable materials on drying kinetics during fluidized bed drying. Journal of Food Engineering, 58(3): 277-283.
Sharma, G. and Prasad, S. 2004. Effective moisture diffusivity of garlic cloves undergoing microwave-convective drying. Journal of Food Engineering, 65(4): 609-617.

Sharma, G.P., Verma, R.C. and Pathare, P. 2005. Mathematical modeling of infrared radiation thin layer drying of onion slices. Journal of Food Engineering, 71(3): 282-286.

Tasirin, S.M., Kamarudin, S.K., Ghani, J.A. and Lee, K.F. 2007. Optimization of drying parameters of bird's eye chilli in a fluidized bed dryer. Journal of Food Engineering, 80(2): 695-700.

Zhang, Q. and Litchfield, J.B. 1991. An optimization of intermittent corn drying in a laboratory scale thin layer dryer. Journal of Drying Technology, 9(2): 383-395. 